\title{
Taxonomy and biology of a new Oecophoridae (Lepidoptera) from central Chile
}

\author{
Taxonomía y biología de un nuevo Oecophoridae (Lepidoptera) de Chile central
}

\author{
T. HEATH-OGDEN ${ }^{1} \&$ LUIS E. PARRA
}

Departamento de Zoología, Facultad de Ciencias Naturales y Oceanográficas, Universidad de Concepción, Casilla 160-C, Concepción, Chile, e-mail: luparra@udec.cl

${ }^{1}$ Current address: Department of Zoology, 574 Widtsoe Building, Brigham Young University, Provo, Utah 84602, U.S.A., e-mail: heath_ogden@byu.edu

\begin{abstract}
The adult, larva, and pupa of Afdera jimenae Ogden \& Parra sp. nov. are described and illustrated. Larvae live in leaf litter throughout all instars and are generalists feeding upon the fallen leaves of a number of different plant species of sclerophyllous forests. Comments on morphological details and bionomics of this species are given. This is the second species of Afdera know for Chile.
\end{abstract}

Key words: Afdera jimenae, biology, leaf litter, Oecophoridae, sclerophyllous forest, taxonomy.

\section{RESUMEN}

Se describe e ilustra el adulto, larva y pupa de Afdera jimenae Ogden \& Parra sp. nov. Los diferentes estados larvarios se encuentran en la hojarasca del bosque esclerófilo de la Península de Hualpén, alimentándose de hojas en descomposición de diferentes especies vegetales. Se entregan comentarios sobre detalles morfológicos y bionómicos de la especie. Esta es la segunda especie de Afdera descrita para Chile.

Palabras clave: Afdera jimenae, biología, bosque esclerófilo, hojarasca, Oecophoridae, taxonomía.

\section{INTRODUCTION}

The Chilean Oecophoridae are different from most other gondwanan oecophorids because they lack ocelli (Clark 1978), there are only a few species which also lack ocelli in Australia (Nielsen \& Common 1991). This endemic character can be explained because Chile has been considered to be a biogeographical island due to the desert on the north, the Andes to the east, and the ocean to the west and south (Armesto et al. 1995, Villagrán \& Le Quesne 1996). The only tropical American genus that extends into Chilean territory is Gonionota Zeller. The other genus that crosses the biogeographical barriers being present in Chile, in the Andes and the Juan Fernandez Islands, and widespread throughout the holarctic region is Depressaiodes Turati.

The oecophorid fauna of Chile has been considered to be "very large" and endemic, having over 62 described species (Clarke 1978). Considering that there are over 4,000 described species worldwide of which half occur in Australia (Scoble 1995), it is likely that Chile has many more spe- cies yet to be discovered. This paper increases the knowledge of this interesting group, giving a detailed description of one species, including many important biological and ecological considerations.

\section{MATERIAL AND METHODS}

All specimens of A. jimenae were collected by us and deposited in the following museums: the Museo de Zoología of Universidad de Concepción, Concepción (MZUC), the Museo Nacional de Historia Natural of Santiago (MNHN), The Natural History Museum at London (BMNH), and the United States National Museum of Natural History of Smithsonian Institution, Washington, District of Columbia (USNM). Adults were either captured using entomological nets or were raised from larvae. The larvae were collected from leaf litter, which was placed into Berlese funnels. Terminology for genitalia and wing maculation follows Scoble (1995). 
RESULTS

\section{Descriptions}

Afdera jimenae Ogden \& Parra sp. nov. Type material examined. Chile, Península de Hualpén, VIII Región. Holotype $1 \sigma^{\top}$ September 26, 1998; Alotype 1 September 26, 1998; Paratypes. $6 \sigma^{7}$ September 26, 1997; 1 ○ October 1, 1998; $1 \sigma^{\top}$ October 13, 1998; 1 October 21, 1998; 2 O November 24, 1998; 5 September 26, 1997; 19 November 3, 1998; 6 O November 24, 1998 (MZUC); 2 October 16, 1998; 2 November 19, 1998 (MNHN); 1 O November 19, 1998; 1 O October 8, 1998 (BMNH); 1 o September 26, 1997; 1 Septemeber 26, 1997 (USNM).

Immature stages. Chile, Península de Hualpén, VIII Región, 16 larvae March 26, 1998; 17 larvae April 2, 1998; 20 larvae April 14, 1998, 21 larvae April 28, 1998; 18 larvae May 15, 1998; 8 larvae June 4, 1998 (MZUC). 2 pupas September 20, 1998 (MZUC).

Diagnosis. Small oecophorid species. Distinguished from A. orphnaea (Meyrick), the only other representative of this genus, by its spoonshaped uncus, wider valves, and longer, and curved sacculus processes. Male and female are very similar, having a fairly uniform dark brown color throughout the entire body.
Male (Fig. 1). Wing expansion: 13-16 mm. Head: with dark brown smooth scales, interior side of maxillary palps creamy-yellow; maxillary palps extend forward tapering, three times the length of the head; proboscis long, two galea totally associated; eyes large, hairless; ocelli absent; antenna filiform, approximately 0.80 the length of the forewing, covered with sensilla as long as the width of the flagellum; scape and pedicel scaled; pecten absent; flagellum with two rows of scales per segment. Thorax: dorsal side dark brown, lighter brown on ventral side; forewing dark brown; all veins present; hindwing dark brown, almost as long as length forewing; apex more tapered; single frenulum. Abdomen: dorsal side dark brown, lighter brown on ventral side. Genitalia (Fig. 2a and 2b); saccus ending in a point; valves large, swollen; sacculus process large and curved inwards, like the horns of a bull; posterior region of juxta with a pair of swellings; gnathos sclerotized, wide, posterior region rounded; uncus large with a spoon shaped swelling; aedeagus slightly curved 0.5 length of total genitalia.

Female. Wing expansion: 15-18 mm. Head: color pattern similar to male; palps, eyes, and proboscis similar to male; antenna similar to male, but with fewer, much shorter sensilla. Thorax and abdomen similar to male. Hindwing with two setae next to the frenulum. Genitalia (Fig. 2c):

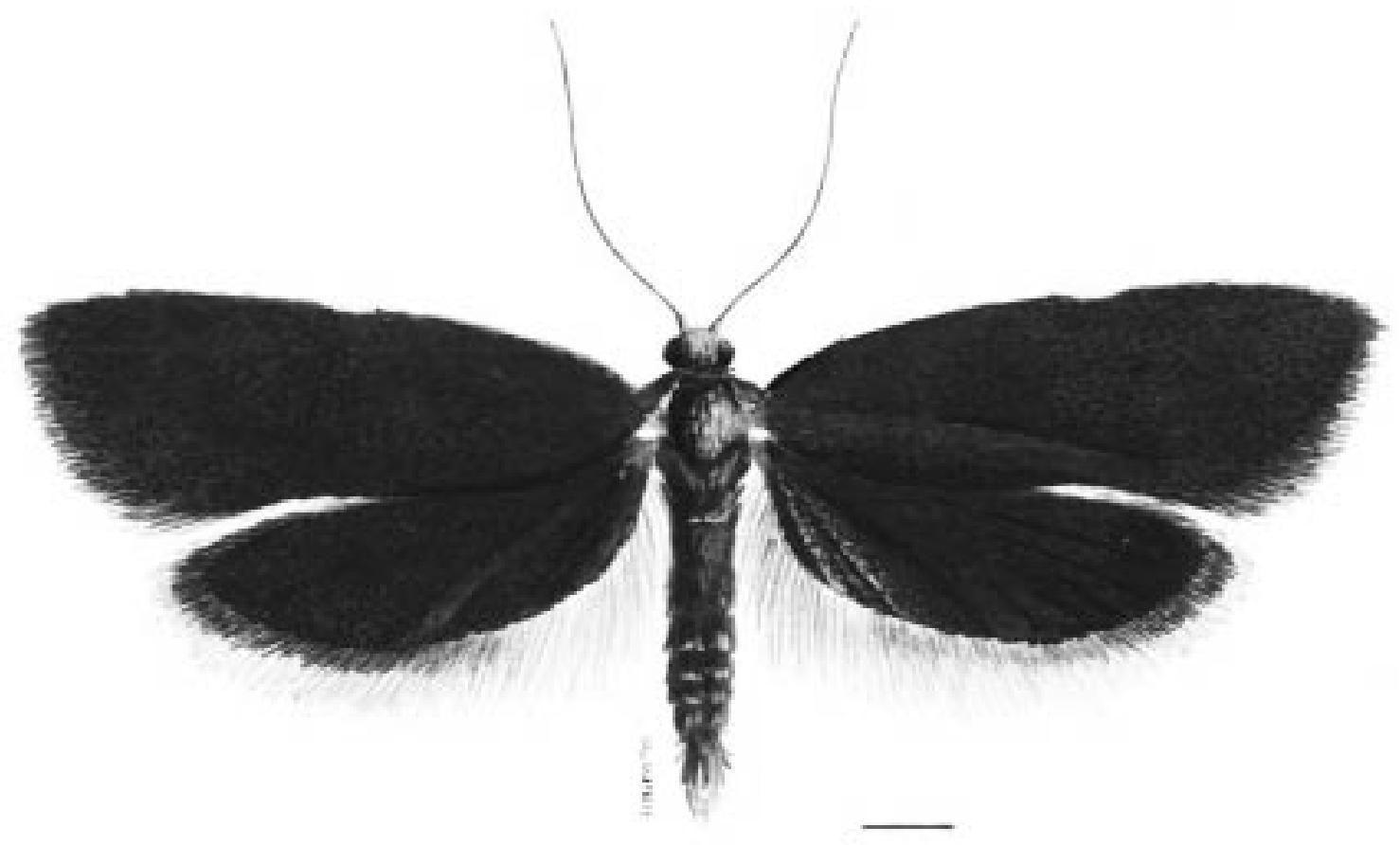

Fig.1: Adult of Afdera jimenae sp. nov. Scale: $1 \mathrm{~mm}$.

Adulto de Afdera jimenae sp. nov. Escala: $1 \mathrm{~mm}$. 

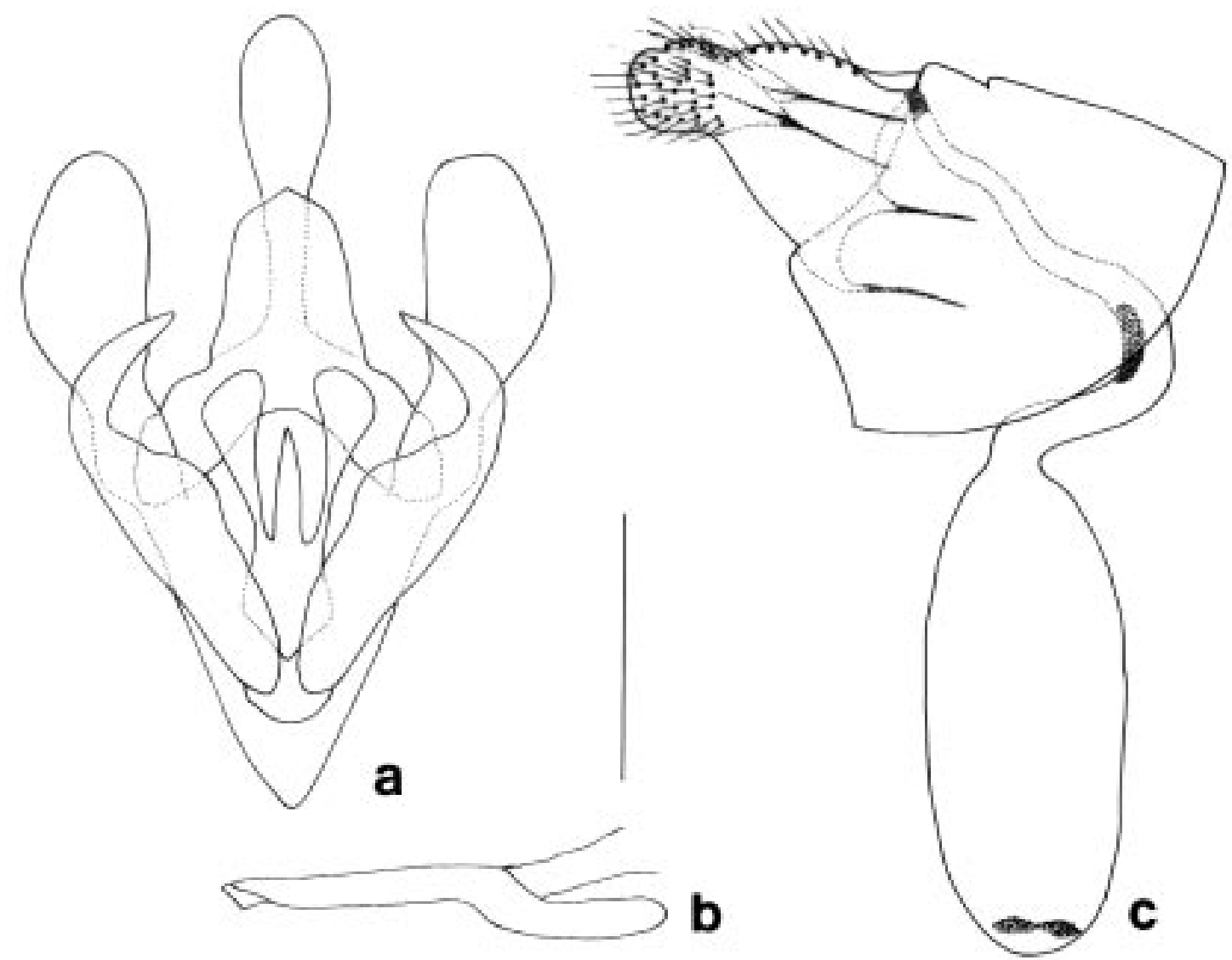

Fig. 2: Afdera jimenae. (a) Male genitalia in ventral view; (b) aedeagus in lateral view; (c) female genitalia in lateral view. Scale: $0.5 \mathrm{~mm}$.

Afdera jimenae. (a) Genitalia del macho en vista ventral; (b) aedeagus en vista lateral; (c) genitalia de la hembra en vista lateral. Escala: $0,5 \mathrm{~mm}$.

corpus bursae large, elongate, with signum in a band shape placed anteriorly; ductus bursae in "U" shape, sclerotized in the inferior portion of the "U"; antrum tubular; ostium bursae as in Fig. $2 \mathrm{c}$; posterior apophysis short, reaching the midpoint of the ostium bursae in length; anal papillae short, rounded, with setae.

Larva (Fig. 3b, 4a, 4c). Total length of last instar $10 \mathrm{~mm}$, maximum width $2 \mathrm{~mm}$. Larvae of early instars of a creamy-yellow color with hints of red, brown, and black around the dorsal setae. Last instars reddish brown in color and black around dorsal setae. Brown sclerotized head, prothoracic, lateral, dorsal, and anal plates. Head (Fig. 3b): hypognathous; spinneret as in Fig. 4b; six stemmata organized as in Fig. 4a; all dorsal setae arise from pinacules. Chaetotaxy as in Fig. 3a. Prolegs well developed with circular, uniordinal crotchets (Fig. 4c).

Pupa (Fig. 3c and 3d): brown; apical end rounded with two pair of setae; frons subrectangular, with two pairs of setae; pair of setae in the corner of the eye-piece region; antenna and proboscis reaching the same point just below the forewing; a pair of setae on the prothorax; two pairs of dorsal and lateral setae on the mesothorax. The apex of wing reaches between the $4^{\text {th }}$ and $5^{\text {th }}$ abdominal segment. Abdomen with two dorsal setae on abdominal segments 1-8; subdorsal setae on segments 29; spiracles on segments 3-8; two lateral setae on segments 4-8; subventral setae on segments 4-7; ventral setae on segments 5-7. Cremaster elongate in the form of a hook (Fig. 4d). Anus and genital orifice as in Fig. 4d.

Biology. This moth presents one generation annually, life cycle is indicated in Fig. 5. The larvae begin to emerge at the end of January. They continue to grow from instar to instar throughout summer, winter, fall, and even the beginning of the following spring. All instars are free living and are found among the leaf litter layer of the soil. They are negatively phototactic and prefer places of higher humidity, and voluminous leaf litter (more than $30 \mathrm{~mm}$ depth). The diet 

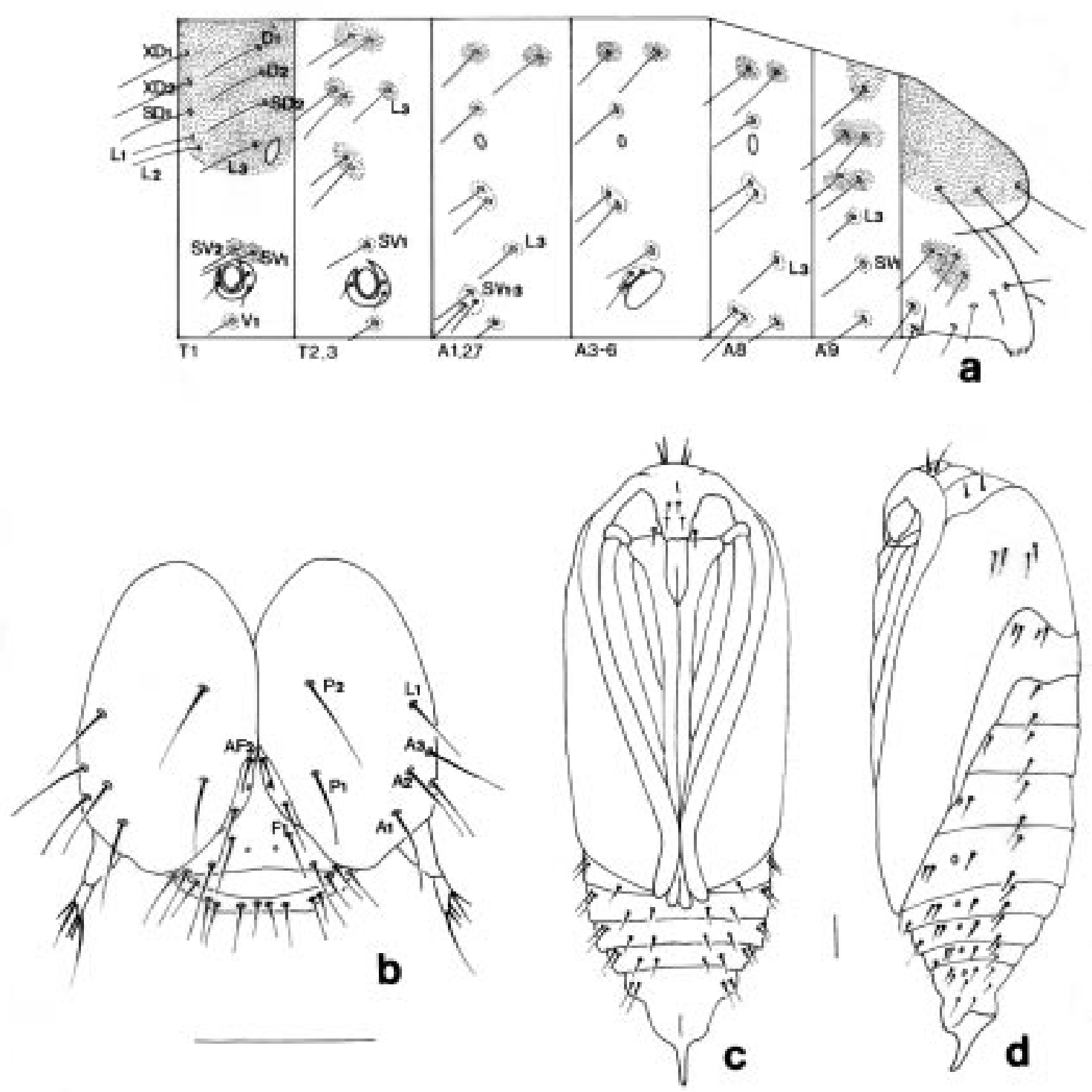

Fig. 3: Morphological structures of the immature stages of A. jimenae. (a) Larval chaetotaxy in lateral view; (b) head of larva in frontal view; (c) pupa in frontal view; (d) pupa in lateral view. Scale: $0.5 \mathrm{~mm}$. Estructuras morfológicas de los estados inmaduros de A. jimenae. (a) Quetotaxía de la larva en vista lateral; (b) cabeza de la larva en vista frontal; (c) pupa en vista frontal; (d) pupa en vista lateral. Escala: 0,5 mm.

is composed of fallen leaves of various species of plants of the sclerophyllous forest (Cryptocarya alba, Aextoxicon punctatum, Peumus boldus, Lithrea caustica, among others). Observations indicated that while feeding the larva takes a small piece of leaf, holding on to it with its forelegs, and the mandibles bite off small fragments starting from the edge and moving inward.

Pupation begins in August and extends until October. The last instars construct a pupal chamber in which metamorphosis takes place. The chamber is constructed from silk and small stones, soil, and organic particles. The pupal exhuvium remains stuck inside the chamber when the adult emerges.

Adults were collected flying or resting between the months of October, November, and part of December. They are day flyers. It is uncertain what they feed as adults, or even if they do indeed feed as adults. It is unknown where oviposition takes place, but it is thought it takes place in leaf litter.

Etymology. The specific name is dedicated to Jimena C. Ogden, spouse of T. Ogden. 

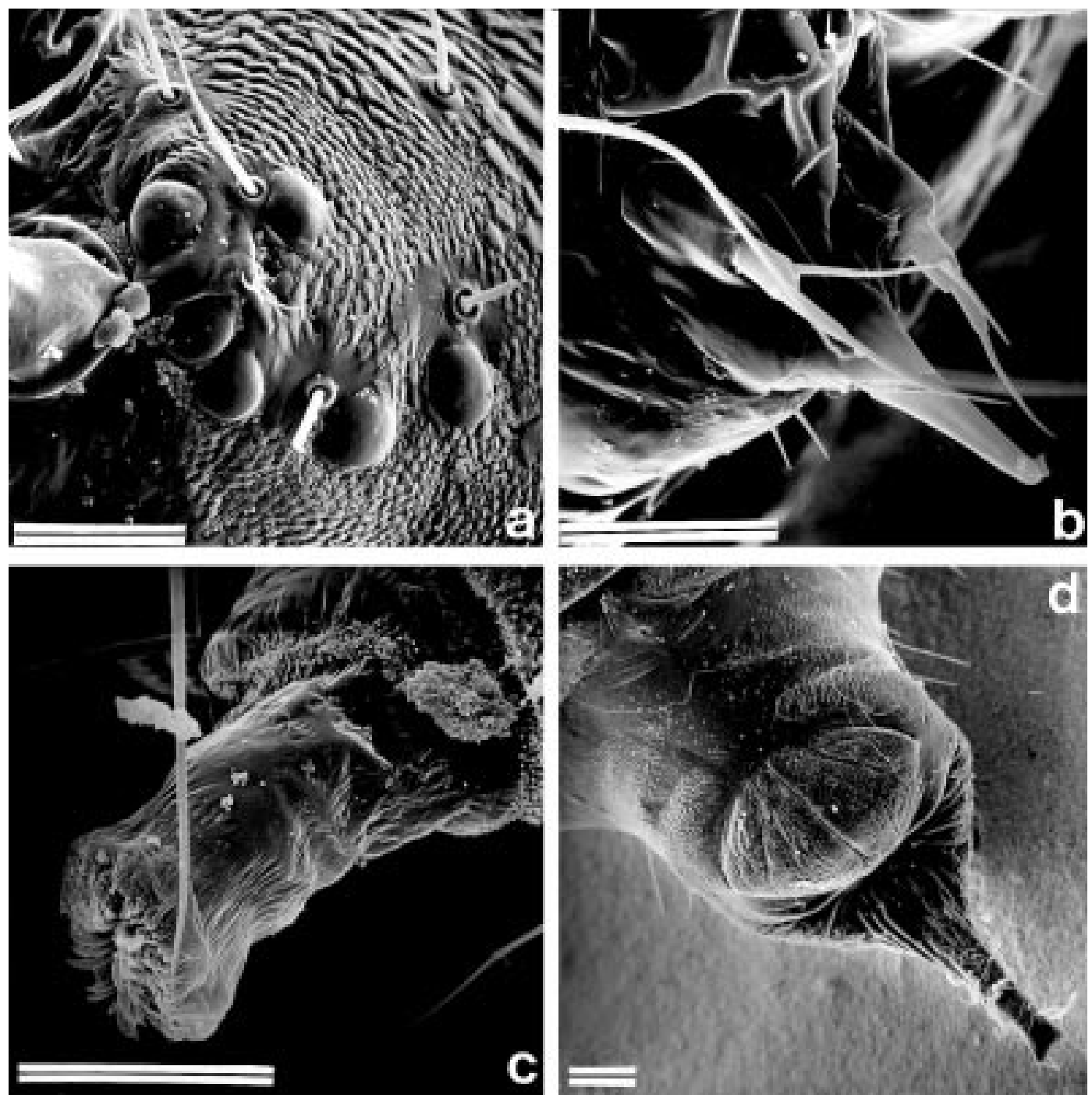

Fig. 4: Morphological structures of the immature stages of A. jimenae. (a) Stemmata; (b) spinneret; (c) proleg and crotchets; (d) anus and genital orifice of pupa. Scale: $100 \mu \mathrm{m}$ (Fig. 4a, 4c and 4d), $50 \mu \mathrm{m}$ (Fig. 4b).

Estructuras morfológicas de los estados inmaduros de A. jimenae. (a) Ocelos; (b) espinerete; (c) espuripedios y crochets; (d) orificio anal y genital de la pupa. Escala: $100 \mu \mathrm{m}$ (Fig. 4a, 4c y 4d), $50 \mu \mathrm{m}$ (Fig. 4b).

\begin{tabular}{|c|c|c|c|c|c|c|c|c|c|c|c|c|}
\hline \multicolumn{13}{|l|}{ Adult } \\
\hline Pupa & & & & & & & & & & & & \\
\hline \multicolumn{13}{|l|}{ Larva } \\
\hline \multicolumn{13}{|l|}{ Egg } \\
\hline & Jan & Feb & Mar & Apr & May & Jun & Jul & Aug & Sep & Oct & Nov & Dec \\
\hline
\end{tabular}

Fig. 5: Life cycle of A. jimenae.

Ciclo de vida de A. jimenae. 
DISCUSSION

Afdera jimenae is the second species of Afdera found in Chile. The other known species is $A$. orphnaea, not seen by us but known only by the male genitalia, as made by Clarke (1978), and used for comparison (see diagnosis).

This is the second published study addressing what is known about the biology of oecophorids in Chile. Another species, Doina collimamolae Parra, is associated with the Luma apiculata (A.P. de Candolle) Burret (Myrtaceae) and Myrceugenia obtusa (D.C.) Berg (Myrtaceae) (Hormazábal et al. 1994), and also presents a univoltine life cycle in the same vegetational type as A. jimenae.

In A. jimenae, the veins Rs and M1 of the hind wing are nearly parallel and the male has a beaklike gnathos. The larvae, similar to Australian genera, feed on dead leaves on the forest floor. These characters permit it to be included into the subfamily Oecophorinae (Nielsen \& Common 1991).

Thus far, the species has only been collected from the Península of Hualpén ( $36^{\circ} 45^{\prime}-36^{\circ} 49^{\prime} \mathrm{S}$, $73^{\circ} 9^{\prime}-73^{\circ} 13^{\prime} \mathrm{W}$ ), but future efforts will be made by the authors to determine the complete distribution. The vegetation of Península of Hualpén is dominated by Cryptocarya alba (peumo) and Aextoxicon punctatum (olivillo), and less extensively, by Peumus boldus (boldo) and Lithrea caustica (litre) (Polymeris 1995). This area has suffered progressive fragmentation and degradation due to anthropic interaction. This vegetation is of special phytogeographic interest as it is a transitional zone between the mesophylic vegetation of the Mediterranean climate and the hygrophylic vegetation of southern South America. The native forest lacks representatives of the genus Nothofagus and includes other less abundant species, such as Drimys winteri (canelo), Eucryphia cordifolia (ulmo), Laurelia sempervirens (laurel) and a few Myrtaceae. Because of the lack of data, we cannot be sure that there is a definite relationship between this insect and this type of vegetation, although its distribution most likely follows that of the temperate forest distribution southward and into the Andes.

\section{ACKNOWLEDGMENTS}

We would like to thank Dr. D. Davis from the Smithsonian Institute (Washington) for helping during species determination. Financial support was obtained from the Dirección de Investigación, Universidad de Concepción, grants 98.113.0471.1D and 200.113.056-1.0.

\section{LITERATURE CITED}

ARMESTO JJ, P LEÓN \& MK ARROYO (1995) Los bosques templados del sur de Chile y Argentina: una isla biogeográfica. En: Armesto JJ, C Villagrán \& MK Arroyo (eds) Ecología de los bosques nativos de Chile: 23-49. Editorial Universitaria, Santiago, Chile.

CLARKE JFG (1978) Neotropical Microlepidoptera, XXI: new genera and species of Oecophoridae from Chile. Smithsonian Contributions to Zoology 273: 1-80.

HORMAZÁBAL ME, LE PARRA \& H IBARRA-VIDAL (1994) Biología reproductiva y morfología de Doina collimamolae, nueva especie de esqueletizador del arrayan (Luma apiculata) (Lepidoptera: Oecophoridae). Tropical Lepidoptera 5: 109-116.

NIELSEN ES \& IFB COMMON (1991) The insects of Australia. Cornell University Press, Ithaca, New York. $1137 \mathrm{pp}$.

POLYMÉRIS CM (1995) Vegetación actual de la Península de Hualpén: clasificación y dinámica. Tesis de Magister en ciencias con mención en botánica. Universidad de Concepción, Concepción, Chile. 190 pp.

SCOBLE MJ (1995) The Lepidoptera: form, function, and diversity. Oxford University Press, Suffolk, United Kingdom. 404 pp.

VILLAGRÁN C \& C LE-QUESNE (1996) El interés biogeográfico-histórico de Chile Central-Sur: ¿por qué debemos conservar su biota? En: Muñoz M, H Núñez \& J Yáñez (eds) Libro rojo de los sitios prioritarios para la conservación de la diversidad biológica de Chile: 160-172. Ministerio de Agricultura, Corporación Nacional Forestal, Santiago, Chile. 203 pp. 